\title{
The Analysis of Structural Contradictions and Countermeasures in the China's Current Economic Operation
}

\author{
Xiaohong Zhao \\ Department of Business Administration \\ Hebei College of Industry and Technology \\ Shijiazhuang,Hebei,050000 China
}

\begin{abstract}
At present, the structural contradictions in the China's economic operation are more obvious, induding the imbalance of the industrial structure, demand structure, income distribution structure, and the structure of factor inputs. The current economic situation in the US. and Europe are not optimistic and China's economic development is risky. Therefore, in today's society, only after discovering and resolving structural problems in economic development and optimizing the economic structure, we will achieve economic stability and healthy development.
\end{abstract}

Keywords-The solution of structural contradictions, optimization, structure and the stability of economy

\section{INTRODUCTION}

In recent years, in order to reduce the adverse impact of the crisis on the Chinese economy, China has proposed to maintain growth, expand domestic demand, adjust structure and promote reform, in order to achieve 8 percent economic growth target. Because of the appropriate government macro-control, a recovery in the economy achieved, and external de mand conditions improved significantly. However, it is undeniable that a new economic growth point in the real economy has not yet appeared, the driving force of economic growth remain largely external policy, and we do not realize a change from the internal mechanism to the market-driven and the external economic environment is so changeable that the external economic recovery is among the shock. Various economic indicators are signals that there is a risk in the current economy and economic structural contradictions highlight a serious impact on the sustainable development of the economy. Despite the economy's structural contradictions is a common phenomenon, this phenomenon is more prominent and troublesome because of the institutional is sues. Therefore, the key to solve the economic structural contradictions is to deepen reform and transform the economic growth mode.

\section{CURRENT STRUCTURALCONTRADICTIONS IN CHINA'S ECONOMIC OPERATION}

Currently the main contradiction which exists in China's economic operation is structural imbalance. The outstanding performance of the structural imbalance is that there exist a shortage of goods and backlogs and it is difficult to buy and sell simultaneously. This contradiction occurs after the economic reform. In the short economy, there is a general shortage on the market, and therefore buyers always face difficulty during the commodity exchange. Before China's reform, the phenomenon of long lines to buy things and the ticket of supplies is typical of the reaction of a seller's shortage economy. As the economic reform, the supply situation in China's market has undergone significant changes. Firstly, compared with before reforms, from the perspective of market, the strength of supply shortage has weakened, slack increased, the number of products in short supply reduced. And secondly, the number of long-term products continue to increase, the backlog of warehouse are more serious, a considerable number of non-production slack are invalid to supply.

In recent years because the amount of China changes faster than the structure of China, it can't adjust the production structure suited to the changing of needs of the industrial structure. With the development of production, China's overall situation is still in a seller's market, during the commodity exchange no smooth deep-rooted contradictions occurs, and it is simultaneously difficult for buyers and sellers. Buyers complain they can't buy what they want to buy and the initial demand is difficult to be met. And then sellers complain they can't sell what they want to sell easily and people are more and more captious about products. Businesses, as buyers and sellers, often complain that selling is more difficult than buying and buying needed raw materials is easier than selling products. So salesmen get more and more attention.

The phenomenon that backlog and shortage coexist is difficult for buyers and sellers simultaneously. Although in seller's market, the total contradiction that is insufficient supply exists in macro economy, but with the weakening of the intensity of shortage and the growing of buyer's market. For this economy, "shortage" is no longer essential 
characteristics. This is because, first, in this economy, "forced substitution" is not so important. For hopeful buyers who has raised their level of consumption, and want to meet their initial require ments, the "hold out until goods" is better than "mandatory alternative." Second, with the growth of the degree of satisfaction, buyers have increasing demands for quality, which asks the dynamic economic development to improve the product quality. Due to the improvement of quality always lags behind the increasing of number, in this delay period, the backlog of product increased. From the analysis we can say that our country's economy is not the typical "shortage economy" as Cornejo describes. In addition to our main contradictions which are facing other "short-term constraints", such as energy and transportation, the more important is the structural imbalance.

\section{THE ANALYSIS OF REASONS FOR THE FORMATION OF DIFFICULTIESOF CHINA'SECONOMIC OPERATION CURRENTLY}

In recent years, China's macro economy is into the increasingly difficult state. Although there are many reasons, the most fundamental reason is that with the sustained and rapid development of China's economy and the rapid increase of material wealth of society, the whole society failed to reach a common understanding of how to deal with the relationship of fair and efficiency at the age of the early reforms. Especially accompanied by the increase intensification of unfair income distribution, society even had a doubt about market-oriented reform, and then wavered between fairness and efficiency, so that the reform is almost stagnant down, or even return to the planned economy in a few areas and it results in market mechanisms and excessive government intervention programs coexist, thus disrupting the order of the market economy and undermining the effective operation of the market economy mechanism.

\section{A. The lag of transformation of government functions and public financial construction}

Under the socialist market economic system, the main duty of the government is to provide to the society with the public goods and services which the community market can not solve, more specifically, which means the government needs to provide effective community management and provide rural and urban public infrastructure, basic education, basic research, public health, health care and other social security pension, as well as a good ecological environ ment. However, in recent years the Chinese government has been to develop the economy in the first place. Regardless of the cost of investment, government at all levels provide funding for the development of enterprises and provide security and low-cost or even free land and a large number of policies and measures from the central government to local governments is to support the introduction and development of companies. The government and enterprises form an integrate, but the taxable income for all citizens to support minority businesses is not only unfair, which results in the unfairness between the same industry enterprises, unfairness among different industries, between residents and businessmen but also the direct cause of social inequities rapidly increasing in recent years, undermining the competitive mechanism of market economy, leading companies do not study the market, but try to research the government. It has seriously affected the enterprise to the market and fair competition and enhancing enterprise competitiveness and innovation. From a practical perspective, industry and enterprise which get government support, lying in the arms of the government, relaxing the day, are facing excess capacity or the single product. Few grow into a strong competitive strength, and most are the lack of ability to respond to the market. Government uses more financial resources to support the development of enterprises, but the result is that public goods and services the government provides are seriously shortages for economic development. Currently, social security, basic education, public health, environmental protection, quality and safety, and social management, are seriously lagging behind needs of social and economic development and impact the simultaneous increase of effective social consumers' demand and economic development. Development of social undertakings lags behind seriously affects the expansion of employment opportunities and leads the largely conflict between economic development and employment difficulties.

\section{B. The slow marketization process of interest rate}

To the normal operation of the market economy, the key is to free flow of production factors, and then to guide the rational flow of factors of production mechanism, which means the price, a factor of production, is able to reflect supply and demand on time. Interest rates and the exchange rate is a reflection of supply and demand of capital factors of production, therefore, to give full play to guiding the rational flow of capital, interest rates should reflect the supply and demand of capital on time, that is, to have a market-oriented interest rate decision mechanism. Currently, the process of reform of China's market-oriented interest rate and exchange rate is slow, interest rates can not reflect the supply and demand of domestic capital and the interest rate does not reflect the supply and demand of international capital. The result is that the flow of capital does not only reflect requirements of efficiency, but also give government to intervene capital flows. In recent years, private enterprises, small and mediu m enterprises, high-tech enterprise get loans difficultly and disorder of finance exist generally underground banks, shadow bank. There is a close relationship with non-market interest rate decision mechanis m. In recent years, there exists a high level of prices, but interest rates fail to reflect changes in the price level. The low level of interest rates results in the emergence of the hunger for the funding and with the increasing scale of investment, the real estate bubble began to swell and form the impulse that government and enterprises jointly invest, which buries a severe financial security risks. In recent years, the imbalance of China's foreign trade is getting worse, foreign exchange reserves grew by leaps and bounds, and the exchange rate of RMB basically has not changed much, 2008 - 2012, \$ 100 from 694 yuan exchange fell to 624 yuan, basically no appreciation of RMB against U.S. dollar. Exchange rate basically stable, seemingly maintaining the stability of the RMB and foreign economic environment, and 
protecting the stable development of foreign trade, but China's foreign trade imbalances and the United States and other countries take easy monetary policy, which result in the rapid growth of China's foreign exchange reserves, induce mild domestic inflation and the continuous depreciation of the renminbi in the country. In the international currency exchange, according to a calculation of purchasing power parity, the relative appreciation of the renminbi reflects the yuan is undervalued and causes a serious imbalance in foreign trade, the market mechanism is eased through the form of inflation and the issue renminbi is undervalued is solved by handing over some of the products of labor. By the end of March 2013, China's foreign exchange balance of the full aperture is about 27.068 trillion yuan, which in March 2013 new foreign exchange is 236.3 billion yuan. Plus 295.426 billion yuan in February, and 683.659 billion yuan in January, a quarter of China's new foreign exchange amounted to 12,154 billion, a new record. The imbalance of foreign trade and the rapid increase in foreign exchange reserves lead to a significant portion of GDP be invisible transferred to foreign consumers, which is an important reason for why in recent years, China's economic growth and the growth of well-being of the residents is not synchronized.

\section{The operation philosophy formed by Local government}

Under China's current administrative system, local governments do not have hard binding for the budget and liabilities and operating risks formed by local government ultimately be borne by the central government, which is borne by all citizens. Therefore, if allowed to take the way of the liability to operate local construction, the local government will have the desire to build an unlimited liability. Therefore, in the condition that current budget of the local government is no hard-binding, you should not allow the debt of the construction of local government. But in recent years, local governments in China have gradually developed a concept of operations, with a variety of stateowned assets, including financial resources to be securities to obtain loans from financial institutions, the central government to help local governments issue bonds, various financial institutions to help finance local government through innovating financing products, so that the local government has become a operating businesses. In the case of asymmetric information, the local government was easy to get funds, but a serious financial security issues buried. At present, the burden of China's local government debt is heavy and the ability to repay the debt relied on land revenue. Once the real estate industry began to cool, the risk of local government debt will suddenly be revealed and impact the whole financial security seriously.

\section{ANALYSIS OF COUNTERMEASURES TO SOLVE THE CONTRADICTION BETWEEN ECONOMIC STRUCT URES}

Fiscal policies dominate, monetary policy be further refine, good macroeconomic policies mix, in order to maintain economic develop stablely. Fiscal policy should be relatively relaxed and diversified. General direction of fiscal policy should be expansionary, but should be based on supply management. Such as reducing corporate taxes is not only to stimulate enthusiasm for production, increase supply and stimulate economic growth, and increase the supply and help curb rising prices, so this policy can simultaneously achieve two goals, economic growth and curbing inflation. Future fiscal policy strengthens investment in specific areas, such as to stimulate domestic demand and support the infrastructure in the Midwest, to increase investment in affordable housing and irrigation and water conservancy and so on.

Strengthen independent innovation, transform the mode of economic growth and promote comparative advantage to competitive advantage. China has participated in the international division by labor-intensive industries for a long time, but has fallen into a "comparative advantage trap". The future adjustment and optimization of economic development pattern has a close relationship with the change from comparative advantage to competitive advantage and leading industry achieve transition from labor-intensive model to capital and technology-intensive industries, which we need a national strategy which is to enhance the capability of independent innovation and build innovationoriented country.

Reduce tax and enrich people, improve people's livelihood, build a consumer-led economic growth has become a key in determining whether achieve sustainable development of China's economy. First of all, it is to reduce government investment and increase people's disposable income through fiscal tax rebates, tax return, tax cuts, a substantial increase of labor compensation share of GDP, the increasing of disposable income of urban residents. In order to switch on consumption, Government investment in the production area must be compressed. Government investment is in fact going short on consumer industries. Because the massive government investment, and even the implementation of deficit financing, in essence, is to let all the people bear more debt, in fact, is to reduce domestic demand. Second, establish a sound social security system and stabilize the price level. The problem of insufficient domestic consumption, in fact, is not a lack of private consumption, but the lack of public consumption, which means the government did not spend the money which should be spent on people's livelihood. Therefore, the government should increase investment in livelihood areas. Accelerate the pace of improvement of education, health care, pension, housing and other systems to reduce the worries of the people, improve the enthusiasm of the people for consumption and increase optimistic expectations domestic residents have for a stable life in the future, prompting them to consume largely.

\section{A. Avoidweaknesses, strengthen supervision and promote the moderately development of the virtual economy}

The purpose of the development of the virtual economy is to promote the development of the real economy, provide effective space for the real economy and improve the efficiency of the real economy. In order to development of the virtual economy, in the aspect of macroeconomic policy, it is necessary to create conditions to make the best use of 
circumstances to promote the development of virtual economic, strengthen management, and prevent risks.

\section{REFERENCES}

[1] State Information Center, in 2002, "there are four national economic decline, experts recommend issuing bonds to cut interest rates again", "Shenzhen Economic Daily", May 17.

[2] People's Bank of China Monetary Policy Analysis Group, 2002, "in the second quarter monetary policy report," People's Daily, August 2.
[3] China Securities Regulatory Commission, 2002, "Statistics show: April before financing halved year on year," Securities Times panoramic Network, May 17.

[4] Jia Kang et al, 2002, "How to treat the tax increase and tax cuts advocated", "Ministry of Finance Research Institute research report" on 17, March 27.

[5] Zhou Xuefei, 2002, "Beware of China's financial system" financing failure, "risk", "Ministry of Finance Research Institute Research Report" on 8, January 25. 